\title{
Development of Adobe Animate Assisted Physics Learning Media as Online Learning Aid
}

\author{
Lintang Rizham Prakasiwi ${ }^{1,{ }^{*}}$ Warsono ${ }^{2,}$ Theofilius Gratimus Gusemanto ${ }^{1,}$ \\ Herawati $^{1}$
}

\author{
${ }^{1}$ Master of Physics Education, Faculty of Mathematics and Natural Sciences, Universitas Negeri Yogyakarta, \\ Indonesia \\ ${ }^{2}$ Department of Physics Education, Faculty of Mathematics and Natural Sciences, Universitas Negeri \\ Yogyakarta, Indonesia \\ ${ }^{*}$ Corresponding author. Email: lintangrizham.2019@student.uny.ac.id
}

\begin{abstract}
This research is a type of development research using the 4D model (Four D Models). Developing a tool in studying and delivering physics material for teachers and students is the aim of this study. The media in question is physics learning media assisted by Adobe Animate on the harmonious vibration material on the spring. Furthermore, it is hoped that Adobe Animate assisted physics learning media can help teachers and students in delivering and studying physics material through online learning. The trial subjects of this study were students of class X MIA 4 SMA N 1 Banguntapan Bantul which consisted of 34 students. The result of this research is that a learning media assisted by Adobe Animate has been developed on harmonious vibration material as a tool for teachers and students in online learning. Physics learning media assisted by Adobe Animate is suitable for use in online physics learning with the "Very Appropriate" category according to media and material experts, as well as according to physics learning practitioners. Physics learning media assisted by Adobe Animate is also very interesting to use during the physics learning process online in the "Very Interesting" category according to the students.
\end{abstract}

Keywords: Learning media, Adobe animate, Online learning

\section{INTRODUCTION}

Physics is a scientific knowledge which is closely related to everyday life [1]. Therefore, it is important for a student to understand the concept of physics from what the teacher says during the physics learning process. However, there are still some students who have difficulty learning and understanding the concepts of physics. This can be caused by the assumption of students who feel physics is a subject that is difficult to understand [2], [3]. One of the influencing factors is the lack of instructional media used during physics learning [4].

Learning media can be an important element in the learning process. Nowadays, the learning media used are more varied due to the rapid development of technology [5]. The use of instructional media can be a tool for teachers and students in delivering and understanding physics material, so that the material can be easier to understand [6]. If during the learning process it is assisted by the existence of learning media, the learning process can be carried out more effectively and efficiently [7]. Thus, the selection of the correct and appropriate learning media will affect the success of the learning process [8].

One of the learning media that can be used in the physics learning process is learning media based on Adobe Animate. Adobe Animate was previously known as Adobe Flash Professional, Macromedia Flash, and FutureSplash Animator [9]. Learning media based on Adobe Animate is an application that can be operated via a smartphone and computer or laptop [10]. Adobe Animate can be used as variance in the learning process [11]. Furthermore, Adobe Flash can be one of the interactive learning media suitable for use as a physics learning media [12]-[14]. Learning media assisted by Adobe Animate has also proven 
feasible to be used by students to learn physics independently [15].

Independent learning by students, one of which can be done by online. Online learning that is increasingly being implemented can provide benefits for students in accessing the required information. Accessing this information can be done without limitation of time and place [16] and age limit [17]. Another benefit obtained from online learning is that students can improve their abilities and skills in using new technology [17].

According to students, online physics learning is a positive thing, especially in the aspects of content and pedagogical structure [18]. In addition, according to students, online learning can be a supporter of face-toface learning [19]. With these problems, it is necessary to develop a physics learning media assisted by Adobe Animate. This learning media is expected to be used by students and teachers as a tool in learning physics online.

\section{RESEARCH METHOD}

This research is a type of development research using the 4D model. The purpose of this research is to develop a product in the form of physics learning media assisted by Adobe Animate. This product is expected to be a tool for teachers and students during online physics learning, especially in the subject of vibrations in harmony with springs. The stages in developing physics learning media assisted by Adobe Animate are carried out in accordance with the stages in the 4D model, namely Define, Design, Develop, and Disseminate

The trial subjects of this study were students of class X MIA 4 SMA N 1 Banguntapan Bantul which consisted of 34 students. The research instrument used was in the form of a product feasibility questionnaire given to media and material experts, as well as physics learning practitioners, in this case the physics teacher at SMA N 1 Banguntapan Bantul. Meanwhile, to determine the attractiveness of the product used an instrument in the form of a product attractiveness questionnaire given to students. The data that has been obtained are then processed using equation 1 below:

Percentage $=\frac{\text { Score }}{\text { Maximum Score }} \times 100 \%$

\section{RESULT AND DISCUSSION}

\subsection{Define}

The aim of this research is to develop a physics learning media that can make it easier for teachers and students to carry out physics learning online. The defining stage is important to do in order to find out what is needed in developing a product. The definition stage was carried out by conducting a preliminary study through analysis of related articles, observing learning activities at SMA N 1 Banguntapan, and interviewing physics teachers. Analysis of the curriculum is also carried out, so that the products developed are in line with existing core and basic competencies. As a result, it was found that there is a need for physics learning media that can help students and teachers in online learning in the midst of a pandemic. Physics learning media can be made interactively with the help of Adobe Animate. The harmonic vibration material on the spring was chosen as the physics material used in this physics learning media assisted by Adobe Animate.

\subsection{Designing}

In developing physics learning media assisted by Adobe Animate, the reference used follows the results of the product's definer and design framework. The product design framework consists of: initial product layout design, placement of logos, buttons, and content, as well as choosing the color used as the product background.

\subsection{Developing}

Physics learning media assisted by Adobe Animate was developed using the Adobe Animate CC 2017 application. This physics learning media consists of 4 menus or sections, namely: the Core Competency menu, Learning Indicators, and Learning Objectives; Tune Vibration Menu; Menu How to Use, and Menu About the Application. In addition, in physics learning media assisted by Adobe Animate, there is also the identity of the media and agencies from the product maker which is placed on thesection Splash Screen.

In physics learning media assisted by Adobe Animate, there are some simple animations about the harmonious vibration material in the spring. One of the simple animations used is an animation that describes the energy contained in harmonious vibrations. This simple animation can be seen in Figure 1, as follows: 


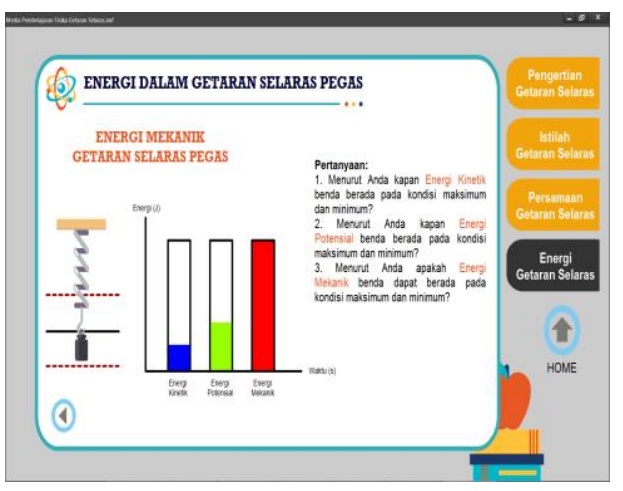

Figure 1 Simple animation of energy in harmonic vibration on a spring

The simple animation in Figure 1 is an oscillating spring accompanied by a graph that describes the energy state of the spring when the spring is isolated. The use of this simple animation can make it easier for students to understand the vibration material in harmony with the spring. Simple animation contained in learning media is considered to be able to help stimulate students in improving their problem-solving skills [20]. In addition, the learning process with the help of animation media can help students improve physics learning outcomes [21].

In addition to simple animation, physics learning media assisted by Adobe Animate also contains material, sample questions, and practice questions related to harmonious vibrations of springs. Furthermore, here is a description of the parts of physics learning media assisted by Adobe Animate which are contained in Table 1:

Table 1. Description of adobe animate-based physics learning media

\begin{tabular}{|c|c|c|}
\hline Part name & Image & Description \\
\hline Splash Screen & $\begin{array}{l}\text { Figure } 2 \text { Splash screen physics learning media with } \\
\text { adobe animate assistance }\end{array}$ & $\begin{array}{l}\text { Contains product identity and product } \\
\text { manufacturer institutions. Can also } \\
\text { function as a product cover }\end{array}$ \\
\hline Main Menu & $\begin{array}{l}\text { Figure } 3 \text { Main menu adobe animate assisted } \\
\text { physics learning media }\end{array}$ & $\begin{array}{l}\text { Is a section that contains the main } \\
\text { navigation buttons that will direct the } \\
\text { user to the sub-section that you want } \\
\text { to go to }\end{array}$ \\
\hline $\begin{array}{l}\text { Basic Competencies, } \\
\text { Learning Indicators, } \\
\text { and Learning } \\
\text { Objectives }\end{array}$ & 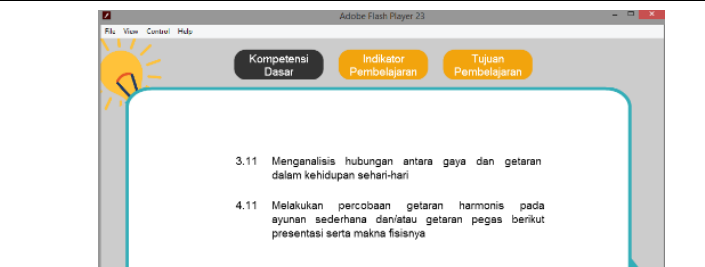 & $\begin{array}{l}\text { Contains Basic Competencies, Learning } \\
\text { Indicators, and Learning Objectives } \\
\text { which are used as references in making } \\
\text { physics learning media assisted by } \\
\text { Adobe Animate }\end{array}$ \\
\hline
\end{tabular}




\begin{tabular}{|c|c|c|}
\hline Part name & Image & Description \\
\hline & $\begin{array}{l}\text { Figure } 4 \text { Basic competency menu, learning } \\
\text { indicators, and learning objectives adobe animate } \\
\text { assisted physics learning media }\end{array}$ & \\
\hline $\begin{array}{l}\text { Harmonious } \\
\text { Vibrations }\end{array}$ & $\begin{array}{l}\text { Figure } 5 \text { Harmonious vibration menu adobe } \\
\text { animate assisted physics learning media }\end{array}$ & $\begin{array}{l}\text { This section contains physics material, } \\
\text { namely harmonious vibrations of } \\
\text { springs. The Harmonious Vibration } \\
\text { menu is divided into a menu of } \\
\text { Harmonized Vibration Definition, } \\
\text { Harmonious Vibration Terms, } \\
\text { harmonious Vibration Equations, and } \\
\text { harmonized vibration energy. In the } \\
\text { Harmonious Vibration menu also } \\
\text { displayed some simple animations, } \\
\text { sample questions, and exercises that } \\
\text { can help students understand the } \\
\text { harmonious vibration material. }\end{array}$ \\
\hline Instructions for Use & Figure 6 Menu instructions for use aligned adobe & $\begin{array}{l}\text { This menu contains instructions for } \\
\text { using physics learning media assisted } \\
\text { by Adobe Animate which can make it } \\
\text { easier for users to operate products }\end{array}$ \\
\hline About the Application & 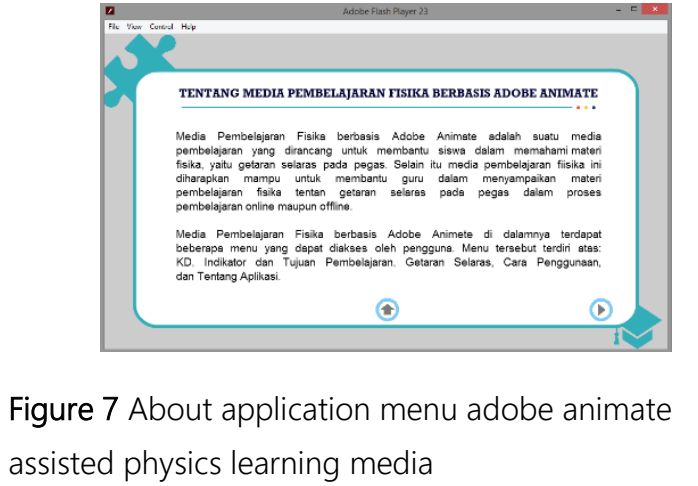 & $\begin{array}{l}\text { This section contains brief information } \\
\text { or information on physics learning } \\
\text { media assisted by Adobe Animate. }\end{array}$ \\
\hline
\end{tabular}

\subsubsection{Validation by Material and Media Experts}

The results of validation of physics learning media assisted by Adobe Animate by material and media experts can be seen in Figure 8, as follows: 


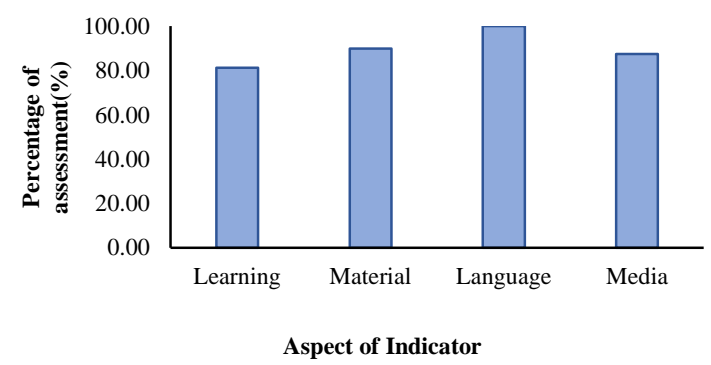

Figure 8 Validation results of adobe animate assisted physics learning media by media and material experts

Figure 8 shows that the learning media Physics assisted by Adobe Animate on the language aspect has the highest percentage of assessment according to material experts and media experts, namely $100 \%$. It can be said that this media has used standard Indonesian and does not cause multiple interpretations for users. In the material aspect, physics learning media assisted by Adobe Animate received an assessment from material and media experts with a percentage of $90.00 \%$. Meanwhile, in the media and learning aspects, this media received an assessment from material and media experts respectively with a percentage of $87.50 \%$ and $81.25 \%$.

Overall, the physics learning media assisted by Adobe Animate obtained an average percentage of assessment of $87.93 \%$. This value shows that the physics learning media assisted by Adobe Animate is suitable for use as a tool in learning physics online, with the Very Appropriate category according to material and media experts. This is in line with Rezeki and Ishafit's research, that learning media based on Adobe Flash (now Adobe Animate) is suitable for use as a medium for learning physics [14]. Besides being feasible, the use of learning media with Adobe Flash can affect the mastery of students' competencies to be better, compared to not using them [22].

\subsubsection{Validation by Physics Learning Practitioners}

The results of the validation of physics learning media assisted by Adobe Animate by physics learning practitioners can be seen in Figure 9, as follows:

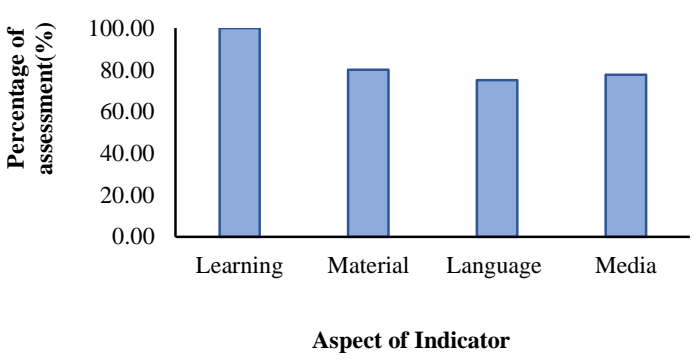

Figure 9 Validation results of physics learning media based on adobe animate by physics learning practitioners learning

Media assisted by Adobe Animate according to physics learning practitioners get a value on the learning aspect with a percentage of $100 \%$. In the material aspect, according to the physics learning practitioner this media gets a score of $80 \%$. Meanwhile, in the media and language aspects, respectively, the scores were obtained with a percentage of $77.78 \%$ and $75 \%$.

So, overall physics learning media assisted by Adobe Animate get an assessment from physics learning practitioners with an average of $81.03 \%$. These results indicate that the physics learning media assisted by Adobe Animate falls into the Very Appropriate category and can be used in the physics learning process online.

Physics learning practitioners, in applying validation, do not provide comments or suggestions on the products being developed. This means that the physics learning media assisted by Adobe Animate is feasible or can be used in the physics learning process without experiencing improvement.

\subsubsection{User Responses}

Students' responses to physics learning media assisted by Adobe Animate are by doing physics learning online through Google Classroom on the vibration material in harmony with the spring. Google Classroom is one of the commonly used online learning platforms and is no stranger to students [23]. In addition, the use of Google Classroom as an online learning tool can help teachers because it is easy to use and can be monitored in real time [24]. Not only easy to use by teachers, Google Classroom is also an online learning platform that is easy to use by students [25].

The use of physics learning media assisted by Adobe Animate gets responses from students which can be seen in Figure 10, as follows: 


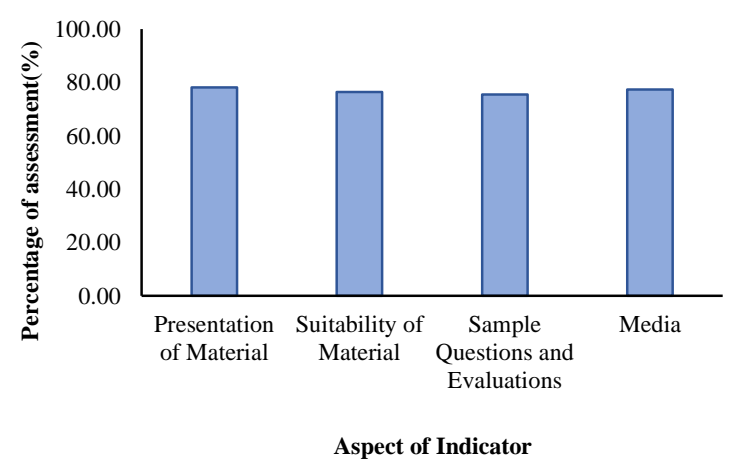

Figure 10 Student responses to physics learning media based on adobe animate

Physics learning media assisted by Adobe Animate in the presentation aspect of the material gets the highest response from students is $78.22 \%$. Furthermore, in the media aspect, students responded to the physics learning media assisted by Adobe Animate is $77.46 \%$. Then, in the aspect of presenting the material and sample questions and evaluating them respectively, the physics learning media received responses from students is $76.52 \%$ and $75.51 \%$. So, it can be concluded that the response of students to physics learning media assisted by Adobe Animate is $76.93 \%$ in the Very Interesting category.

In addition to providing responses through several aspects of indicators, students also commented on the use of physics learning media assisted by Adobe Animate as a tool in online learning. Students assume that using physics learning media assisted by Adobe Animate can help them understand the material presented, namely the harmonious vibrations of the spring. This is in line with previous research, that physics learning media assisted by Adobe Flash can help students improve their understanding of physics concepts [13]. In addition, according to students, physics learning media assisted by Adobe Animate is interesting to use during online physics learning. Anggreani and Kustijono in their research also said that learning using Adobe Flash can increase interest for students [26].

\subsection{Disseminate}

Dissemination or dissemination is carried out on products that have been developed through reporting and dissemination of products at meetings and scientific journals.

\section{CONCLUSION}

The conclusion obtained based on the research conducted is that a learning media assisted by Adobe Animate has been developed on the subject of vibrations in harmony with springs. This learning media can function as a tool for teachers and students in learning physics online. Physics learning media assisted by Adobe Animate is suitable for use in online physics learning with the "Very Appropriate" category according to media and material experts, as well as according to physics learning practitioners. Physics learning media assisted by Adobe Animate is also very interesting to use during the physics learning process online in the "Very Interesting" category according to the students.

\section{REFERENCES}

[1] A. Saregar, Pembelajaran Pengantar Fisika Kuantum dengan Memanfaatkan Media PhET Simulation dan LKM melalui Pendekatan Saintifik: Dampak pada Minat dan Penguasaan Konsep Mahasiswa, Jurnal Ilmiah Pendidikan Fisika Al-Biruni 5(1) (2016) 53-60. DOI: https://doi.org/10.24042/jpifalbiruni.v5i1.105

[2] Irmawati, M. Djalaluddin, A. Wahyuni, Pengaruh Model Pembelajaran Kooperatif Physics Mysterious Berbasis Fun Learning terhadap Minat dan Hasil Belajar, Jurnal Pendidikan Fisika UIN Alaudding Makassar 5(1) (2017) 6-9. DOI: https://doi.org/10.24252/jpf.v5i1.2991

[3] H. Rosdianto, E. Murdani, Hendra, Implementasi Model Pembelajaran Poe (Predict Observe Explain) untuk Meningkatkan Pemahaman Konsep Siswa pada Materi Hukum Newton, Jurnal Pendidikan Fisika 6(1) (2017) 55-57. DOI: https://doi.org/10.22611/jpf.v6i1.6899

[4] H.A. Agustin, S. Bektiarso, R.W. Bachtiar, Pengembangan Modul Komik Fisika pada Pokok Bahasan Hukum Kepler di SMA Kelas XI, Jurnal Pembelajaran Fisika 7(2) (2018) 168-174. DOI: https://doi.org/10.19184/jpf.v7i2.7924

[5] F. Adnan, B. Prasetyo, N. Nuriman, Usability Testing Analysis on The Bana Game as Education Game Design References on Junior High School, Jurnal Pendidikan IPA Indonesia 6(1) (2017) 88-94. DOI: https://doi.org/ 10.15294/jpii.v6i1.9597

[6] U.N. Labibah, I. Wilujeng, S. Sulaiman, L. Rahmawati, Android-Based Physics Learning 
Media Integrated Landslide Disaster, Jurnal Ilmiah Pendidikan Fisika Al-Biruni 8(2) (2019) 229-236.

DOI: https://doi.org/10.24042/jipfalbiruni.v0i0.4695

[7] G.T.S. Putra, M.W.A. Kesiman, I.G.M. Darmawiguna, Pengembangan Media Pembelajaran Dreamweaver Model Tutorial pada Mata Pelajaran Mengelola Isi Halaman Web untuk Siswa Kelas XI Program Keahlian Multimedia di SMK Negeri 3 Singaraja, Jurnal Nasional Pendidikan Teknik Informatika 2(2) (2013) 125-141. DOI: https://doi.org/ 10.23887/janapati.v2i2.9782

[8] E. Marpanaji, M.I. Mahali, R.A.S. Putra, Survey on how to select and develop learning media conducted by teacher professional education participants, in: Journal of Physics: Conference Series, vol. 1140, IOP Publishing, Bristol, 2018, pp. 1-10. DOI: https://doi.org/10.1088/17426596/1140/1/012014

[9] F. Lardinois, Adobe Launches Animate CC, Previously Known As Flash Professional, Tech Crunch, Sep. 2016. Accessed on: Sep. 23, 2020. [Online]. Available:

https://techcrunch.com/2016/02/08/adobelaunches-animate-cc-previously-known-as-flashprofessional/

[10] S. Muslim, N.P. Gitama, B. Suprianto, E. Rahmadyanti, N. Kusumawati, Influence of Learning Media Based on Adobe Flash Professional to Psychomotor Domain Learning Outcomes on PLC Courses Viewed from Level of Creative Thinking Student, Jurnal Pendidikan Vokasi 8(3) (2018) 267-276. DOI: https://doi.org/10.21831/jpv.v8i3.21552

[11] U. Umbara, A. Rosyid, D.L. Setiawan, Pelatihan Pembuatan Media Pembelajaran Matematika Berbasis Flash Menggunakan Adobe Animate bagi Guru SMP di Kabupaten Kuningan, Jurnal Pengabdian Pada Masyarakat 4(1) (2019) 93104.

DOI: https://doi.org/10.30653/002.201941.84

[12] S.D. Aji, M.N. Hudha, C. Huda, G. Gufran, Computer animation with adobe flash professional cs6 in newton's law, in: IOP Conference Series: Materials Science and Engineering, vol. 288, IOP Publishing, Bristol, 2018, pp. 1-3. DOI: https://doi.org/ 10.1088/1757-899X/288/1/012131
[13] P. Aswirna, P. Yulianti, R. Fahmi, N.A. Agustin, Adobe flash development using interaction treatment aptitude to improve the reasoning of kinetic theory of gas and thermodynamic materials, in: Journal of Physics: Conference Series, vol. 1467, IOP Publishing, Bristol, 2020, pp. 1-13. DOI: https://doi.org/10.1088/1742$\underline{6596 / 1467 / 1 / 012012}$

[14] S. Rezeki, Ishafit, Pengembangan Media Pembelajaran Interaktif untuk Sekolah Menengah Atas Kelas XI pada Pokok Bahasan Momentum, Jurnal Penelitian dan Pengembangan Pendidikan Fisika 3(1) (2017) 29-34. DOI: https://doi.org/10.21009/1.03104

[15] Susilawati, R. Oktova, D.P.N. Lestari, Media pembelajaran fisika modern berbasis android menggunakan adobe flash CS6 dengan animasi tiga dimensi pada materi model atom untuk siswa kelas XII SMA," in Prosiding SNFA (Seminar Nasional Fisika dan Aplikasinya), vol. 1, Universitas Sebelas Maret, Surakarta, 2017, pp. 233-240. DOI: https://doi.org/10.21009/1.03104

[16] Y. Yuberti, Online Group Discussion pada Mata Kuliah Teknologi Pembelajaran Fisika, Jurnal Ilmiah pendidikan Fisika Al-Biruni 4(2) (2015) 145-153.

DOI: https://doi.org/10.24042/jpifalbiruni.v4i2.88

[17] T.A. Kumari, C.H. Hemalatha, M.S. Ali, R. Naresh, Survey on impact and learning's of the online courses on the present era, in: Procedia Computer Science, vol. 172, Elsevier, Amsterdam, 2020, pp. 82-91. DOI: https://doi.org/10.1016/j.procs.2020.05.167

[18] W. Ng, E. Angstmann, Promoting Physics Literacy through Enquiry-Based Learning Online, Journal of Education in Science Environment and Health 3(2) (2017) 183-195. DOI: https://doi.org/10.21891/jeseh.326750

[19] D. Rahadian, S.H. Bariyah, I. Nasrullah, Y. Purwanti, K. Imania, Development of online learning design, in: Journal of Physics: Conference Series, vol. 1402, IOP Publishing, Bristol, 2019. pp. 1-5. DOI: https://doi.org/10.1088/17426596/1402/6/066044

[20] Z. Chen G. Gladding, How to Make A Good Animation: A Grounded Cognition Model of How Visual Representation Design Affects The Construction Of Abstract Physics Knowledge, Physical Review Physics Education Research 
10(1) (2014) 1-24. DOI: https://doi.org/10.1103/PhysRevSTPER.10.0101 $\underline{11}$

[21] I. M. Astra, D. Susanti, S. Sakinah, The effects of cooperative learning model think pair share assisted by animation media on learning outcomes of physics in high school, in: Journal of Physics: Conference Series, vol. 1521, IOP Publishing, Bristol, 2020, pp. 1-7. DOI: https://doi.org/10.1088/1742$\underline{6596 / 1521 / 2 / 022005}$

[22] G.R. Astatin, H. Nurcahyo, Pengembangan Media Pembelajaran Biologi Berbasis Adobe Flash untuk Meningkatkan Penguasaan Kompetensi pada Kurikulum 2013, Jurnal Inovasi Pendidikan IPA 2(2) (2016) 165-175. DOI: https://doi.org/10.21831/jipi.v2i2.10966

[23] A. Izenstark, K.L. Leahy, Google Classroom for Librarians : Features and Opportunities, Library Hi Tech News 32(9) (2015) 1-3. DOI: http://dx.doi.org/10.1108/LHTN-05-2015-0039

[24] A. Muslik, Google Classroom sebagai Alternatif Digitalisasi Pembelajaran Matematika di Era Revolusi Industri 4.0, Andragogi Jurnal Diklat Teknis pendidikan dan Keagamaan 7(2) (2019) $246-255$.

DOI: https://doi.org/10.36052/andragogi.v7i2.98

[25] S.A. Hapsari, H. Pamungkas, Pemanfaatan Google Classroom sebagai Media Pembelajaran Online di Universitas Dian Nuswantoro, Wacana Jurnal Ilmiah Ilmu Komunikasi 18(2) (2019) 225233. DOI: https://doi.org/10.32509/wacana.v18i2.924

[26] R.D. Anggraeni, R. Kustijono, Pengembangan Media Animasi Fisika pada Materi Cahaya dengan Aplikasi Flash Berbasis Android, Jurnal Pendidikan Fisika dan Aplikasinya 3(1) (2013) 11-18.

DOI: http://dx.doi.org/10.26740/jpfa.v3n1.p11-18 